\title{
Copper(II) Schiff Base Complexes with Catalyst Property: Experimental, Theoretical, Thermodynamic and Biological Studies
}

\author{
Sheida Esmaielzadeh ${ }^{1}$ and Elham Zarenezhad ${ }^{2, *}$ \\ ${ }^{1}$ Department of Chemistry, Darab branch, Islamic Azad University, Darab, I. R. Iran \\ ${ }^{2}$ Non-communicable Diseases Research Center, School of Medicine, Fasa University of Medical Sciences, Fasa, Iran \\ *Corresponding author: E-mail: el.zarenezhad.fums.@gmail.com
}

Received: 02-01-2018

\begin{abstract}
Two novel copper(II) Schiff base complexes were synthesized and characterized by various physico-chemical and spectroscopic methods, revealing a distorted square planar geometry around the copper atom. The analytical data confirmed the 1:1 metal to ligand stoichiometry of the complexes. B3LYP/(LANL2DZ/6-311 $\mathrm{G}^{* *}$ ) density functional theory (DFT) were used to investigate structural and electronic properties of the synthesized compounds in gas phase. The computational results support the conclusion obtained by the experimental studies. Thermodynamic study of complex formation in solution was carried out spectrophotometrically at $25^{\circ} \mathrm{C}$. These compounds were also subjected to study in vitro antibacterial screening against some bacteria. Also, click reaction was investigated for its catalytic properties. The synthesized Schiff base copper complexes catalyzed 1,3-dipolar Huisgen cycloaddition of different functionalized $\beta$-azido alcohols and alkynes in the presence of ascorbic acid in a solution of $\mathrm{THF} / \mathrm{H}_{2} \mathrm{O}(2: 1, \mathrm{~V} / \mathrm{V})$ at room temperature.
\end{abstract}

Keywords: Copper complex; catalytic activity; antibacterial screening; formation constant; DFT calculations

\section{Introduction}

Schiff bases are an important class of compounds in inorganic chemistry. Research on these compounds has expanded very rapidly over the time and covered several applicative domains. Schiff base ligands and their metal complexes have been employed in areas that include analytical and bioinorganic chemistry, non-linear optics, fluorescence studies, agricultural, pharmaceutical and chemical industries and materials chemistry. ${ }^{1-5}$ Beside the broad range of applications of Schiff base compounds in different field, the metal complexes of Schiff bases are widely used as homogenous and heterogeneous catalyst in reaction. ${ }^{6-8}$ In recent years, the development of efficient new catalysts for several organic reactions like carbonylation, hydroformylation, reduction, oxidation, epoxidation, hydrolysis have received considerable attention as well as for the use as corrosion inhibitors. ${ }^{9-12}$ Among the transition metals, copper has proved to be particularly useful for catalytic applications. Schiff base copper complexes with various types of ligands have shown to possess effective catalytic ability. ${ }^{13-15}$

Based on the above catalytic activity importance of Schiff base complexes and in continuation of our recent work $^{16-19}$ on the Schiff base complexes, in the current investigation, two copper(II) complexes with NNOS coordination sphere have been synthesized and characterized. Catalytic potential have also been explored. The coordination behaviors of the ligands and their complexes, molecular parameter, spectral properties, relative energy and molecular orbital diagrams of all synthesized compounds have been calculated and interpreted with density functional theory (DFT). The antibacterial properties of the compounds against selected kinds of bacteria were also screened and discussed. The thermodynamic parameters of 1:1 complex formation in DMF solvent were determined spectrophotometrically at $25^{\circ} \mathrm{C}$. Due of our interest in the chemistry of azole derivatives ${ }^{20-22}$ we report a new catalyst system based on $\mathrm{Cu}^{\mathrm{II}}$ and ascorbic acid as reducing agent for regioselective 1,3-dipolar Huisgen cycloaddition reaction to access diverse 1,2,3-triazole cores. 1,2,3-Triazole moieties are attractive compounds in medicinal chemistry because of their wide range of applications including use as HIV protease inhibitors, as well as anticancer, anti-tuberculosis, antifungal and antibacterial agents. $^{23}$ 


\section{Experimental}

\subsection{Instruments and Starting Materials}

All chemicals were purchased from Fluka and Merck and were used without further purification. Solvents were purified by standard procedures and stored over $3 \AA$ molecular sieves. Reactions were followed by TLC using SILG/UV 254 silica-gel plates. Column chromatography was performed on silica gel $60(0.063-0.200 \mathrm{~mm}, 70-230$ mesh; ASTM).

The electronic absorption spectra were measured on Perkin Elmer (LAMBDA 2) double beam spectrophotometer in the range of $250-700 \mathrm{~nm}$ in DMF solution at room temperature. The infrared spectra were determined by using $\mathrm{KBr}$ pressed disc method on a Shimadzu FTIR 8300 FT-IR spectrophotometer in the $4000-350 \mathrm{~cm}^{-1}$ region. Melting points were recorded on open capillaries with electronic melting point and are uncorrected. The percentages of $\mathrm{C}, \mathrm{H}, \mathrm{N}$ and $\mathrm{S}$ in synthesized compounds were obtained with a Termo Fininngan-Flash-1200 microanalysis instrument. Mass spectrum performed with Perkin Elmer R MU-6E instrument. The magnetic susceptibilites of the copper complexes were carried out on Sherwood scientific magnetic susceptibility balance calibrated with $\mathrm{Hg}$ $\mathrm{Co}(\mathrm{NCS})_{4}$. Diamagnetic corrections were calculated from Pascal's constants. Molar conductance values $\left(1 \times 10^{-3} \mathrm{M}\right)$ in DMF solution were determined by means of a Jenway 4310 conductivity meter and a diptype cell with a platinized electrode at room temperature. ${ }^{1} \mathrm{H}$ and ${ }^{13} \mathrm{C}$ NMR spectra were obtained using a Brüker Avance-DPX-400 spectrometer operating at $400 / 100 \mathrm{MHz}$, respectively.

\section{2. Synthesis of the Ligand}

Methyl 2-((1-aminopropan-2-yl)amino)cyclopent-1enedithioate and two Schiff base ligands methyl 2-((1((2-hydroxy-5-methoxybenzylidene)amino)propan-2-yl) amino)cyclopent-1-enecarbodithioate, $\mathrm{H}_{2} \mathrm{~L}^{1}$, and methyl 2-((1-((2-hydroxy-5-nitrobenzylidene)amino)propan-2yl)amino)cyclopent-1-enecarbodithioate, $\mathrm{H}_{2} \mathrm{~L}^{2}$, were synthesized according to the previously published procedure. ${ }^{17}$

$\mathrm{H}_{2} \mathrm{~L}^{1}$ :Yield: $83 \%$; m.p.: $152^{\circ} \mathrm{C} .{ }^{1} \mathrm{H}$ NMR $(\delta, \mathrm{ppm}, 400$ $\left.\mathrm{MHz}, \mathrm{CDCl}_{3}\right): 1.39(3 \mathrm{H}, \mathrm{d}, \mathrm{Me}), 1.74\left(2 \mathrm{H}, \mathrm{m}, \mathrm{H}^{4^{3}}\right), 2.56$ $\left(3 \mathrm{H}, \mathrm{s}, \mathrm{SCH}_{3}\right), 2.68-2.72\left(4 \mathrm{H}, \mathrm{m}, \mathrm{H}^{3,5^{\prime}}\right), 3.52-3.55(3 \mathrm{H}, \mathrm{m}$, $\left.\mathrm{H}^{\mathrm{en}}\right), 3.77\left(3 \mathrm{H}, \mathrm{s}, \mathrm{OCH}_{3}\right), 6.73\left(1 \mathrm{H}, \mathrm{s}, \mathrm{H}^{6}\right), 6.86\left(1 \mathrm{H}, \mathrm{d}, \mathrm{H}^{4}\right)$, $7.24\left(1 \mathrm{H}, \mathrm{d}, \mathrm{H}^{3}\right), 8.28(1 \mathrm{H}, \mathrm{s}, \mathrm{CH}=\mathrm{N}), 12.37(1 \mathrm{H}, \mathrm{br}, \mathrm{NH})$ and $12.45(1 \mathrm{H}, \mathrm{br}, \mathrm{OH})$. MS Spectra: $\mathrm{m} / z(\%)=365$ $[\mathrm{M}+\mathrm{H}]^{+}, 364[\mathrm{M}]^{+}, 287,186,166,150,123,97,81,57$. Elemental Anal.: Found (Calc): $\mathrm{C}_{18} \mathrm{H}_{24} \mathrm{~N}_{2} \mathrm{O}_{2} \mathrm{~S}_{2}$, C: 59.07 (59.31); H: 6.75 (6.64); N: 7.84 (7.69); S: 17.32 (17.59\%).

$\mathrm{H}_{2} \mathrm{~L}^{2}$ : Yield: $93 \%$; m.p.: $152^{\circ} \mathrm{C} .{ }^{1} \mathrm{H}$ NMR $(\delta$, ppm, 400 $\left.\mathrm{MHz}, \mathrm{CDCl}_{3}\right): 1.43(3 \mathrm{H}, \mathrm{d}, \mathrm{Me}), 1.79\left(2 \mathrm{H}, \mathrm{m}, \mathrm{H}^{4}\right), 2.55$ $\left(3 \mathrm{H}, \mathrm{s}, \mathrm{SCH}_{3}\right), 2.64\left(2 \mathrm{H}, \mathrm{t}, \mathrm{H}^{3}\right), 2.68\left(2 \mathrm{H}, \mathrm{t}, \mathrm{H}^{5^{\prime}}\right), 3.61-3.66$ $\left(3 \mathrm{H}, \mathrm{m}, \mathrm{H}^{\mathrm{en}}\right), 6.99\left(1 \mathrm{H}, \mathrm{d}, \mathrm{H}^{3}\right), 8.20-8.23\left(2 \mathrm{H}, \mathrm{m}, \mathrm{H}^{4,6}\right)$, $8.46(1 \mathrm{H}, \mathrm{s}, \mathrm{CH}=\mathrm{N}), 12.30(1 \mathrm{H}, \mathrm{br}, \mathrm{NH})$ and $14.06(1 \mathrm{H}, \mathrm{br}$,
OH). MS Spectra: $m / z(\%)=380[\mathrm{M}+\mathrm{H}]^{+}, 379[\mathrm{M}]^{+}, 368$, 257, 236, 121, 111, 83, 58. Elemental Anal.: Found (Calc): $\mathrm{C}_{17} \mathrm{H}_{21} \mathrm{~N}_{3} \mathrm{O}_{3} \mathrm{~S}_{2}$, C: 53.98 (53.81); H: 5.41 (5.58); N: 11.03 (11.07); S: 16.71 (16.90\%).

\section{3. Synthesis of the Copper(II) Complexes}

The $\mathrm{Cu}(\mathrm{II})$ Schiff base complexes were synthesized by the addition of $10 \mathrm{~mL}$ of ethanolic solution of $\mathrm{Cu}(\mathrm{II})$ acetate $(1 \mathrm{mmol})$ dropwise to $10 \mathrm{~mL}$ methanol/chloroform $(1: 2 \mathrm{v}: \mathrm{v})$ of Schiff base ligand $(1 \mathrm{mmol})$ in a round bottom flask. The mixture was stirred on ice bath for $2-3 \mathrm{~h}$. The complex was filtered and washed several times with distilled water. The obtained brown complexes were dried at room temperature. The purity was checked by thin layer chromatography. In spite of all the efforts, single crystal of these complexes could not be crystallized.

[CuL ${ }^{1}$ ]: Yield: $81 \%$, m.p.: $209^{\circ} \mathrm{C} . \Lambda_{\mathrm{M}}=\left(10^{-3} \mathrm{M}\right.$, in DMF, $\left.\mathrm{ohm}^{-1} \mathrm{Cm}^{2} \mathrm{~mol}^{-1}\right): 8.26$; $\mu_{\text {eff: }}$ 1.76. MS Spectra: $\mathrm{m} / \mathrm{z}$ $(\%)=426[\mathrm{M}]^{+}, 369,312,284,250,239,199,184,130,85$, 55. Elemental Anal.: Found (Calc): $\mathrm{C}_{18} \mathrm{H}_{22} \mathrm{~N}_{2} \mathrm{O}_{2} \mathrm{~S}_{2} \mathrm{Cu}, \mathrm{C}$ : 50.82 (50.74); H: 5.06 (5.20); N: 6.33 (6.58); S: 14.82 (15.05\%).

[CuL ${ }^{2}$ ]: Yield: $96 \%$, m.p.: $239^{\circ} \mathrm{C} . \Lambda_{\mathrm{M}}=\left(10^{-3} \mathrm{M}\right.$, in DMF, $\left.\mathrm{ohm}^{-1} \mathrm{Cm}^{2} \mathrm{~mol}^{-1}\right):$ 7.94. $\mu_{\text {eff: }}: 1.75$. MS Spectra: $\mathrm{m} / \mathrm{z}$ $(\%)=442[\mathrm{M}+\mathrm{H}]^{+}, 441[\mathrm{M}]^{+}, 395,380,373,290,267,159$, 111, 69. Elemental Anal.: Found (Calc): $\mathrm{C}_{17} \mathrm{H}_{19} \mathrm{~N}_{3} \mathrm{O}_{3} \mathrm{~S}_{2} \mathrm{Cu}$, C: 46.02 (46.30); H: 4.35 (4.34); N: 9.77 (9.53); S: 14.62 (14.54\%).

\section{4. Catalytic Activity Interpretation}

\section{4. 1. General Procedure for Synthesis of Propargyl aryl (2d, 2e)}

For synthesis of propargyl aryl such as $\mathbf{2 d}, \mathbf{2} \mathbf{e}^{24,25}$, a mixture of phenol or 4-bromophenol (1 mmol), $\mathrm{KOH}(1.2$ $\mathrm{mmol})$ and propargyl bromide $(1 \mathrm{mmol})$ in acetone $(10$ $\mathrm{mL}$ ) was heated in a round-bottomed flask for $4 \mathrm{~h}$ (TLC control). The solvent was then evaporated and dried to afford (ethynyloxy methyl benzene) and (1-bromo-4-(ethynyloxy methyl benzene)) compounds which was used in the next step without further purification.

\section{4. 2. General Procedure for Catalytic Test}

$1 \mathrm{mmol}$ of $\alpha$-haloketone or alkyl halide, alkyne (1 $\mathrm{mmol})$, sodium azide $(1.1 \mathrm{mmol})$, and water $(1 \mathrm{~mL}) / \mathrm{THF}$ $(9 \mathrm{~mL})$ were stirred under reflux for the required time according to Table 3 in the presence of the catalyst ( $1 \mathrm{~mol} \%$ ). The progress of the reaction was monitored by TLC ( $n$-hexane:ethyl acetate $=5: 1$ ), and after the completion of the reaction, the remaining suspension was dissolved in $\mathrm{CHCl}_{3}(100 \mathrm{~mL})$ and subsequently washed with water $(2 \times$ $100 \mathrm{~mL})$. The organic layer was dried $\left(\mathrm{Na}_{2} \mathrm{SO}_{4}\right)$ and evaporated. The crude product was purified by column chromatography on silica gel and eluted with proper solvents. 
Characterization data of two new synthesized compounds $(4 \mathbf{m}, \mathbf{4 n})$ are described below.

(4m): 1-(4-bromophenyl)-2-(4-(phenoxymethyl)-1H-1, 2,3-triazol-1-yl)ethanone

Column chromatography on silica gel $($ EtOAc $/ n$-hexane $=$ 2:1) afforded the product as a yellow product; yield: $89 \%$. ${ }^{1} \mathrm{H}$ NMR ( $\delta$, ppm, $\left.400 \mathrm{MHz}, \mathrm{CDCl}_{3}\right): 5.15\left(2 \mathrm{H}, \mathrm{s}, \mathrm{CH}_{2}-\mathrm{N}\right)$, $5.80\left(2 \mathrm{H}, \mathrm{s}, \mathrm{CH}_{2}-\mathrm{O}\right), 6.71-8.03(11 \mathrm{H}, \mathrm{m}$, arom, H-triazole). ${ }^{13} \mathrm{C}$ NMR ( $\delta$, ppm, $\left.100 \mathrm{MHz}, \mathrm{CDCl}_{3}\right): 115.6,127.1$, 127.7, 128.2, 129.8, 131.3, 132.8, 133.7, 156.2, 166.7, 189.0. IR $\left(\mathrm{KBr}, \mathrm{cm}^{-1}\right): 3069,2860,1725,1341(\mathrm{C}=\mathrm{N}), 1466,1263$. Elemental Anal.: Found (Calc): $\mathrm{C}_{17} \mathrm{H}_{14} \mathrm{~N}_{3} \mathrm{O}_{2} \mathrm{Br}$, C: 54.80 (54.86); H: 3.83 (3.79); N: 11.25 (11.29).

(4n): 2-(4-(phenoxymethyl)-1H-1,2,3-triazol-1-yl)-1phenylethanone

Column chromatography on silica gel $($ EtOAc $/ n$-hexane $=$ 2:1) afforded the product as a yellow product; yield: $83 \%$. ${ }^{1} \mathrm{H} \mathrm{NMR}\left(\delta\right.$, ppm, $\left.400 \mathrm{MHz}, \mathrm{CDCl}_{3}\right): 5.15\left(2 \mathrm{H}, \mathrm{s}, \mathrm{CH}_{2}-\mathrm{N}\right)$, $5.80\left(2 \mathrm{H}, \mathrm{s}, \mathrm{CH}_{2}-\mathrm{O}\right), 6.80-7.93(11 \mathrm{H}, \mathrm{m}$, arom, H-triazole). ${ }^{13} \mathrm{C}$ NMR $\left(\delta, \mathrm{ppm}, 100 \mathrm{MHz}, \mathrm{CDCl}_{3}\right): 54.4,61.1$, 112.4, 115.6, 124.9, 127.1, 128.2, 131.3, 132.8, 133.7, 156.3, 168.4, 189.0. IR $\left(\mathrm{KBr}, \mathrm{cm}^{-1}\right): 3059,2924,1695,1669,1489$, 1220. Elemental Anal.: Found (Calc): $\mathrm{C}_{17} \mathrm{H}_{15} \mathrm{~N}_{3} \mathrm{O}_{2}$ : C: 69.62 (69.61); H: 5.18 (5.16); N: 14.30 (14.33).

\section{5. Details of Calculations}

The geometry optimization of the Schiff base ligands and their complexes were performed by using the gradient-corrected density functional theory (DFT) method with B3LYP functional. ${ }^{26}$ All elements except $\mathrm{Cu}$ were assigned $6-311 \mathrm{G}^{* *}$ basis set. ${ }^{27}$ LANL2DZ with effective core potential for $\mathrm{Cu}$ were used. ${ }^{28}$ The IR frequencies were calculated at the same level of theory with the key word freq

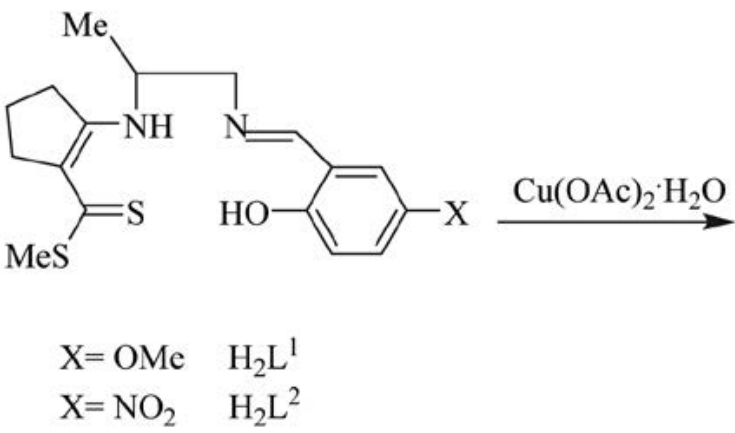

Scheme 1 for the optimized structure in order to confirm structure minima without any imaginary. On the basis of calculations the structure properties, the relative stability, HOMO and LUMO energies and the chemical hardness, Mulliken atomic charges and UV data have been discussed in details. In addition, a comparison was made between the theoretical calculated IR and UV data and the experimental measured. The Gaussian 03 package ${ }^{29}$ with the aid of the Gauss View was employed to obtain the optimized the structures and all the calculations.

\section{6. Antibacterial Assay}

The antibacterial activity of the Schiff base ligands and their $\mathrm{Cu}^{\mathrm{II}}$ complexes against different the bacterial species such as Staphylococcus aureus (Gram positive bacteria) and Escherichia coli (Gram negative bacteria) were determined by reported disk diffusion method ${ }^{30,31}$ using nutrient agar as the medium. Tetracycline was used as standard reference. The stock solution of test compounds were dissolved in dry dimethylsulfuxide (DMSO exhibited no antibacterial activity against the test bacterial pathogens) to get concentration of $1.00 \mathrm{mg} / \mathrm{mL} .100 \mu \mathrm{L}$ of test bacteria spore suspension was spread on nutrient agar plates. Appropriate well were impregnated be equal volume from the test solution of compounds and carefully placed on agar surface. The plates were incubated for $24 \mathrm{~h}$ at $37^{\circ} \mathrm{C}$. The antibacterial activity was evaluated by measuring the clear zone surround of growth inhibition.

\section{Result and Discussion}

The chemical equations concerning the formation of the Schiff base complexes are schematically represented in Scheme 1.

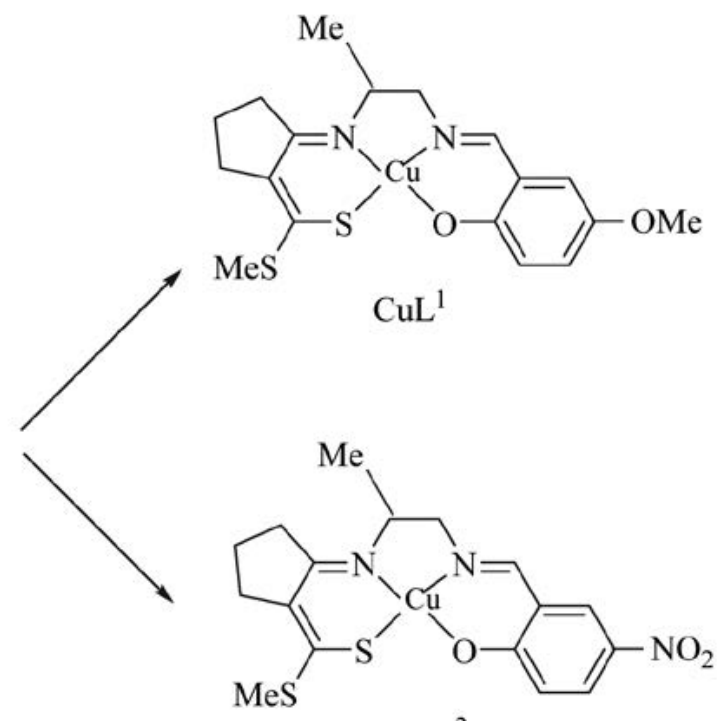

$\mathrm{CuL}^{2}$ 


\section{1. Experimental Results}

\section{1. 1. Spectral Properties}

The elemental analysis, IR and UV-Vis data and the physical properties such as melting points, yields, magnetic susceptibility of the ligands and their complexes were presented in the experimental section and in Tables 1 and 2. These data showed that the complexes has stoichiometry of the type $[\mathrm{ML}]$ where $\mathrm{M}=\mathrm{Cu}$ and $\mathrm{L}=$ Schiff base ligands. All synthesized compounds are stable at room temperature, but decompose on heating. All compounds are insoluble in water but they are readily soluble in DMF, acetonitrile, DMSO and partially soluble in ethanol. The measured molar conductance values in DMF are too low indicating their nonelectrolytic nature of complexes. ${ }^{5,32}$

\section{1. 1. The Characteristic IR Bands}

The IR spectra of Schiff base ligands and their complexes were recorded and their comparative study provides meaningful information regarding the bonding sites of the ligands (see Table 1). The broad band at 3066 and 3413 $\mathrm{cm}^{-1}$ was assigned to the free $v(\mathrm{OH})$ stretching modes in the spectra of Schiff ligands, but in their $\mathrm{Cu}$ (II) complexes this band were not observed, suggesting the chelation of the phenolic oxygen to the copper ion. ${ }^{33}$ The band present in the region $2920-2951 \mathrm{~cm}^{-1}$ is elated to aliphatic and aromatic $\mathrm{C}-\mathrm{H}$ stretching vibrations. ${ }^{34}$ The ligands exhibit imine $v(\mathrm{C}=\mathrm{N})$ stretching around $1600 \mathrm{~cm}^{-1}$. Actually, this strong absorption band was shifted to lower wave numbers (bathochromic shift) in the complexes, indicating the participation of azomethine nitrogen in binding with metal ion. ${ }^{35,36}$ The band observed at around $1440 \mathrm{~cm}^{-1}$ corresponds to the aromatic $\mathrm{C}=\mathrm{C}$ stretching vibration. ${ }^{37}$ Coordination of the Schiff base to the $\mathrm{Cu}(\mathrm{II})$ ion through the carbonyl oxygen atom is expected to decrease the electron density in the carbonyl group frequency. The band due to $v(\mathrm{C}-\mathrm{O})$ showed a modest decrease in the stretching frequency for the complexes and is shifted to lower frequencies after complexation, indicating the coordination of the carbonyl oxygen atom. ${ }^{38}$ A medium to strong intensity band located at 1157, 783 and $1099,752 \mathrm{~cm}^{-1}$ in the $\mathrm{H}_{2} \mathrm{~L}^{1}$ and $\mathrm{H}_{2} \mathrm{~L}^{2}$ ligands are attributed to the stretching mode of the $v(\mathrm{CS}+\mathrm{CN})$ and $(\mathrm{C}=\mathrm{S})$, respectively.
Table 2. Experimental electronic spectral data and their assignment of the compounds in DMF

\begin{tabular}{lcc}
\hline Compounds & $\lambda(\mathbf{n m})$ & Assignment \\
\hline $\mathrm{H}_{2} \mathrm{~L}^{1}$ & 314,398 & $\pi \rightarrow \pi^{*}, \mathrm{n} \rightarrow \pi^{\star}$ \\
$\mathrm{H}_{2} \mathrm{~L}^{2}$ & 313,398 & $\pi \rightarrow \pi^{*}, \mathrm{n} \rightarrow \pi^{*}$ \\
{$\left[\mathrm{CuL}^{1}\right]$} & 328,378 & $\pi \rightarrow \pi^{*}, \mathrm{LMCT}$ \\
{$\left[\mathrm{CuL}^{2}\right]$} & 332,370 & $\pi \rightarrow \pi^{*}, \mathrm{LMCT}$ \\
\hline
\end{tabular}

These band was shifted to lower frequency after complexation, due to coordination with the sulfur atom of the $\mathrm{C}=\mathrm{S}$ group for all the complexes. ${ }^{5,17,39}$ The assignments of bands in the far-IR region are useful as direct information about the metal-ligand coordination bond. The new weak intensity band in the spectra of the $\mathrm{Cu}^{\mathrm{II}}$ complexes in the region $538-546 \mathrm{~cm}^{-1}$ and $443-459 \mathrm{~cm}^{-1}$ are attributed to $v(\mathrm{Cu}-\mathrm{O})$ and $v(\mathrm{Cu}-\mathrm{N})$ bonds, respectively. ${ }^{9,40,41}$ Furthermore, The IR spectra bands at 1332 and $1550 \mathrm{~cm}^{-1} \mathrm{ob}-$ served in $\mathrm{H}_{2} \mathrm{~L}^{2}$ compound are assigned to $v_{\mathrm{s}}\left(\mathrm{NO}_{2}\right)$, $v_{\text {as }}\left(\mathrm{NO}_{2}\right)$ respectively, these absorption bands remained almost at the same position in the $\left[\mathrm{CuL}^{2}\right]$ complex, indicating that nitro group is not involved in coordination. ${ }^{17,18}$

\section{1. 1. 2. Electronic Spectra}

The electronic spectra of the synthesized compounds were investigated in DMF solvent $\left(1 \times 10^{-4} \mathrm{M}\right)$ at room temperature. This technique also confirmed the formation of the ligand and its metal complexes. The Schiff base ligands exhibit a relatively intense intraligand absorption bands. The first intense absorption peak is centered at 395 and $398 \mathrm{~nm}$ for $\mathrm{H}_{2} \mathrm{~L}^{1}$ and $\mathrm{H}_{2} \mathrm{~L}^{2}$, respectively, and corresponds to the $n \rightarrow \pi^{*}$ transition of imine chromofore, while the last peak in high energy ( 316 for $\mathrm{H}_{2} \mathrm{~L}^{1}$ and $313 \mathrm{~nm}$ for $\left.\mathrm{H}_{2} \mathrm{~L}^{2}\right)$ is attributed to the $\pi \rightarrow \pi^{*}$ transition of the aromatic ring, respectively ${ }^{8,42,43}$ (See Table 2 ).

After complexation, a red shift is observed for $\pi \rightarrow \pi^{*}$ transition. The $\mathrm{n} \rightarrow \pi^{*}$ transition disappeares in the spectrum of the complexes due to the coordination of the azomethine nitrogen atom (nitrogen lone pair donation) to the metal ion. ${ }^{33,44}$ The absorption maximum at 378 and $370 \mathrm{~nm}$ which could be assigned to ligand to metal charge

Table 1. Some selected experimental and computed IR vibrational modes $\left(\mathrm{cm}^{-1}\right)$ of the Schiff base ligands and their copper complexes

\begin{tabular}{lccccccccccc}
\hline & compounds & $\boldsymbol{v}(\mathbf{C u}-\mathbf{N})$ & $(\mathbf{C u}-\mathbf{O})$ & $\boldsymbol{v}(\mathbf{C}=\mathbf{S})$ & $\boldsymbol{v}(\mathbf{C}-\mathbf{S}+\mathbf{C}-\mathbf{N})$ & $\boldsymbol{v}(\mathbf{C}-\mathbf{O})$ & $\boldsymbol{v}(\mathbf{C}=\mathbf{C})$ & $\boldsymbol{v}(\mathbf{C}=\mathbf{N})$ & $\boldsymbol{v}(\mathbf{C}-\mathbf{H})$ & $v(\mathbf{O}-\mathbf{H})$ & $\boldsymbol{v}\left(\mathbf{N O} \mathbf{O}_{2}\right)$ \\
\hline Experimental & $\mathrm{H}_{2} \mathrm{~L}^{1}$ & - & - & 783 & 1157 & 1276 & 1481 & 1635 & 2920 & 3413 & - \\
frequencies & $\mathrm{H}_{2} \mathrm{~L}^{2}$ & - & - & 752 & 1099 & 1266 & 1477 & 1649 & 2938 & 3066 & 1332,1550 \\
& {$\left[\mathrm{CuL}^{1}\right]$} & 443 & 546 & 756 & 1145 & 1267 & 1461 & 1612 & 2947 & - & - \\
& {$\left[\mathrm{CuL}^{2}\right]$} & 459 & 538 & 740 & 1090 & 1220 & 1453 & 1610 & 2951 & - & 1335,1548 \\
\hline Calculated & $\mathrm{H}_{2} \mathrm{~L}^{1}$ & - & - & 730 & - & 1260 & 1468 & 1653 & 3041 & 3410 \\
frequencies & $\mathrm{H}_{2} \mathrm{~L}^{2}$ & - & - & 775 & - & 1283 & 1477 & 1668 & 2037 & 3455 & 1343,1519 \\
& {$\left[\mathrm{CuL}^{1}\right]$} & 470 & 555 & 721 & - & 1277 & 1434 & 1636 & 3080 & - & \\
& {$\left[\mathrm{CuL}^{2}\right]$} & 472 & 581 & 743 & - & 1266 & 1460 & 1646 & 3102 & - & 1345,1540 \\
\hline
\end{tabular}


transfer ( $\left.\mathrm{S} \rightarrow \mathrm{Cu}^{\mathrm{II}} \mathrm{LMCT}\right)$. The positions of these bands are similar to those observed for square planar copper(II) complexes. ${ }^{18,19,45}$

\section{1. 1. 3. Mass Spectra Study of the Synthesized Compounds}

The mass spectrum of the Schiff base ligands and their copper(II) complexes were recorded. This technique provided strong evidence for the formation of compounds. These spectra show a molecular ion peaks $\mathrm{M}^{+}$at $m / z 364$, 379,426 and 441 which are in agreement with the empirical molecular formula $\mathrm{C}_{18} \mathrm{H}_{24} \mathrm{~N}_{2} \mathrm{O}_{2} \mathrm{~S}_{2}, \mathrm{C}_{17} \mathrm{H}_{21} \mathrm{~N}_{3} \mathrm{O}_{3} \mathrm{~S}_{2}$, $\mathrm{C}_{18} \mathrm{H}_{22} \mathrm{~N}_{2} \mathrm{O}_{2} \mathrm{~S}_{2} \mathrm{Cu}$ and $\mathrm{C}_{17} \mathrm{H}_{19} \mathrm{~N}_{3} \mathrm{O}_{3} \mathrm{~S}_{2} \mathrm{Cu}$, respectively, suggested from elemental analysis.

\section{1. 1. Magnetic Susceptibility Measurement}

Magnetic moment was measured at room temperature for the $\mathrm{Cu}^{\mathrm{II}}$ complexes. The complexes show the magnetic moment values at 1.75 and 1.76 B.M. corresponding to one unpaired electron with a very slight orbital contribution are quite close to 1.77 B.M. expected for a $S=1 / 2$ as mostly seen for a $\mathrm{d}^{9}$ system, the magnetic moment values reveals that the titled complexes is monomeric in nature without any of metal-metal interaction. ${ }^{5,38}$ The proposed geometry of the copper(II) complexes is a distorted square planar. ${ }^{45}$

The spectral data are very helpful in supporting the proposed tetradentate Schiff base complex structure and coordination pattern in this study.

\section{1. 2. Catalytic Study}

The 'click' 1,3-dipolar Huisgen cycloaddition reaction has been reported in a wide variety of copper(II) complexes. In this work, the click reaction of $\alpha$-haloketones or alkyl halides (1a-i), alkynes (2a-d), and sodium azide in water were performed in the presence of two different $\left[\mathrm{CuL}^{1}\right]$ and $\left[\mathrm{CuL}^{2}\right]$ catalysts (Scheme 2 ).
Using this methodology only one of possible regioisomers was formed (Table 3). Thirteen of the synthesized products 3a-n were known compounds and their identity was confirmed by a comparison of their melting point and their spectral properties with literature data (Table 3). Two products $\mathbf{3 m}$ and $\mathbf{3 n}$ are new, and they were characterized by IR, ${ }^{1} \mathrm{H}$ NMR and ${ }^{13} \mathrm{C}$ NMR spectral data and elemental analysis. The yield and reaction time of the synthesized compounds $\mathbf{3 m}$ and $\mathbf{3 n}$ are presented in Table 3 . Based on the results, the reaction yields with $\left[\mathrm{CuL}^{2}\right]$ catalyst is generally higher than $\left[\mathrm{CuL}^{1}\right]$ catalyst. Also, the catalyst $\left[\mathrm{CuL}^{2}\right]$ required shorter reaction times than catalyst $\left[\mathrm{CuL}^{1}\right]$. Various alkyl, benzyl and benzoyl halides with both electron-donating and -withdrawing substituents were subjected to the same reaction conditions as $\mathbf{3}$ to furnish the corresponding 1,2,3-triazole derivatives.

\section{1. 3. The Formation Constant Interpretation}

Formation constants and thermodynamic parameters are very useful tools for the investigation of interactions between donor and acceptor species and equilibria in solution. In this work, we measured the formation constants of the complexation by UV-Vis spectrophotometric method through titration of a fixed concentration of the ligands $(5 \times$ $\left.10^{-5} \mathrm{M}\right)$ as a donor with one to ten-fold excess of copper acetate $\left(10^{-4}-10^{-5} \mathrm{M}\right)$ as an acceptor at $25^{\circ} \mathrm{C}$ in DMF. The absorption measurements were recorded in the range 250 $700 \mathrm{~nm}$ about $5 \mathrm{~min}$ after each addition. The formed complex exhibited different absorption from the free ligand, while the $\mathrm{Cu}^{\mathrm{II}}$ ion solution showed no absorption at these wavelengths. As an example, the variation of the electronic spectra for $\mathrm{H}_{2} \mathrm{~L}^{1}$ titrated with various concentration of $\mathrm{Cu}^{\mathrm{II}}$ acetate is shown in Figure 1. By the addition of $\mathrm{Cu}^{\mathrm{II}}$ solution to a solution of $\mathrm{H}_{2} \mathrm{~L}^{1}$ ligand, the original band of $\mathrm{H}_{2} \mathrm{~L}^{1}$ at $\lambda_{\max }$ $=314 \mathrm{~nm}$ was weakened and a new intense band appeared at $\left.\lambda_{\max }=376 \mathrm{~nm}\right)$ for the $\left[\mathrm{CuL}^{1}\right]$ complex. Isosbestic points suggest that there are only two species in equilibrium.

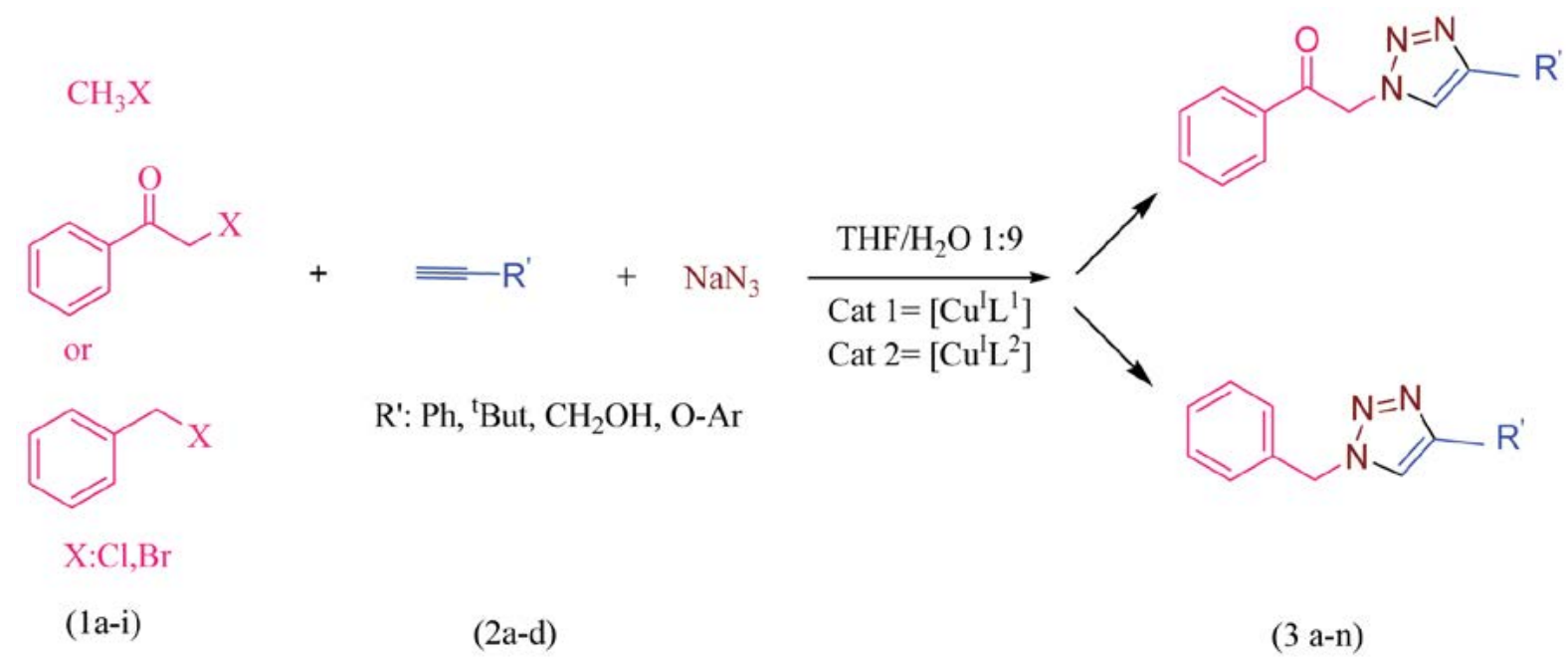

Scheme 2. Synthetic route of Huisgen cycloaddition reaction by the new $\mathrm{Cu}^{\mathrm{II}}$ complexes catalyst. 
Table 3. The cycloaddition reaction with copper(II) Schiff base complexes catalyst.

\begin{tabular}{|c|c|c|c|c|c|c|c|c|}
\hline \multirow[t]{2}{*}{ Entry } & \multirow{2}{*}{$\begin{array}{l}\text { Bromo keton or } \\
\text { Alkyl Halid (1) }\end{array}$} & \multirow[t]{2}{*}{ Acetylens (2) } & \multirow[t]{2}{*}{ Product (3) } & \multicolumn{2}{|c|}{ Time/ (min) } & \multicolumn{2}{|c|}{ GC Yelid } & \multirow{2}{*}{$\begin{array}{l}\text { m.p. }{ }^{\circ} \mathrm{C} \\
\text { (lit) [ref] }\end{array}$} \\
\hline & & & & cat 1 & cat2 & cat1 & cat2 & \\
\hline 1 & & & & 60 & 80 & 81 & 90 & $\begin{array}{c}113-115 \\
(116)[25]\end{array}$ \\
\hline 2 & $\begin{array}{c}\mathrm{CH}_{3} \mathrm{I} \\
1 \mathrm{~b}\end{array}$ & & & 128 & 120 & 75 & 92 & $\begin{array}{c}122-125 \\
(125)[25]\end{array}$ \\
\hline 3 & & & & 40 & 35 & 90 & 95 & $\begin{array}{c}128-130 \\
(129)[24]\end{array}$ \\
\hline 5 & & & & 60 & 42 & 81 & 92 & $\begin{array}{c}111-112 \\
(110[24]\end{array}$ \\
\hline 6 & & & $3 \mathrm{e}$ & 50 & 33 & 78 & 82 & $\begin{array}{c}155-157 \\
(156)[24]\end{array}$ \\
\hline 7 & & & & 20 & 10 & 84 & 92 & $\begin{array}{c}171-172 \\
(169)[25]\end{array}$ \\
\hline 8 & & & & 30 & 20 & 80 & 89 & $\begin{array}{l}155-157 \\
(159)[25]\end{array}$ \\
\hline 9 & & & & 55 & 32 & 86 & 92 & $\begin{array}{c}105-108 \\
(107)[25]\end{array}$ \\
\hline 10 & & & & 60 & 40 & 79 & 83 & $\begin{array}{c}110-113 \\
(115)[25]\end{array}$ \\
\hline 11 & & & & 70 & 50 & 77 & 85 & $\begin{array}{c}155-158 \\
(154)[25]\end{array}$ \\
\hline 12 & & & & 85 & 65 & 80 & 95 & $\begin{array}{c}154-155 \\
(154)[25]\end{array}$ \\
\hline 13 & & & & 75 & 62 & 85 & 92 & $\begin{array}{c}168-171 \\
(170)[25]\end{array}$ \\
\hline 14 & & 20 & & 80 & 72 & 75 & 90 & $\begin{array}{c}197 \text { [this } \\
\text { work] }\end{array}$ \\
\hline 15 & & & & 90 & 95 & 80 & 85 & $\begin{array}{c}182 \text { [this } \\
\text { work] }\end{array}$ \\
\hline
\end{tabular}

The complex formation constant were calculated using the SQUAD computer program, ${ }^{46}$ designed to calculate the best value for the formation constant by employing a non-linear, least square approach. Also, the free energy change, $\Delta \mathrm{G}^{\circ}$, for the formed complexes were determined by $\Delta G^{\circ}=-R T \ln K_{\mathrm{f}}$ at $25^{\circ} \mathrm{C}$ where $K_{\mathrm{f}}$ is the complex forma- 
tion constant, $R$ is the gas constant and $T$ is the temperature in the Kelvin scale (Table 4). The electronic effect of the para substituted Schiff base ligand plays important role in stability and reactivity of their complexes. The methoxy group is an electron donating group (EDG) or electron releasing group (ERG) that donates some of its electron density into a conjugated $\pi$-system via resonance or inductive effects, thus making the Schiff base ligand $\mathrm{H}_{2} \mathrm{~L}^{1}$ more nucleophilic, so the interaction of this ligand results in the formation of the charge transfer complex in which a negatively charged acceptor and positively charged donor interact electrostatically and increase the formation constants. On the other hand, $\mathrm{NO}_{2}$ substituent an electron withdrawing group (EWG) will have the opposite effect on nucleophilicity as an EDG, as it removed electron density from a $\pi$-system making the Schiff base ligand $\mathrm{H}_{2} \mathrm{~L}^{2}$ more electrophilic. The acceptor property of the Schiff base ligand is increased by decreasing the electron donating properties of the $\mathrm{NO}_{2}$ group and therefore leads to decrease the formation constants of the copper(II) complex. Therefore, the formation constant and the free energy data for $\left[\mathrm{CuL}^{1}\right]$ are larger than those for $\left[\mathrm{CuL}^{2}\right]$ (see Table 4).

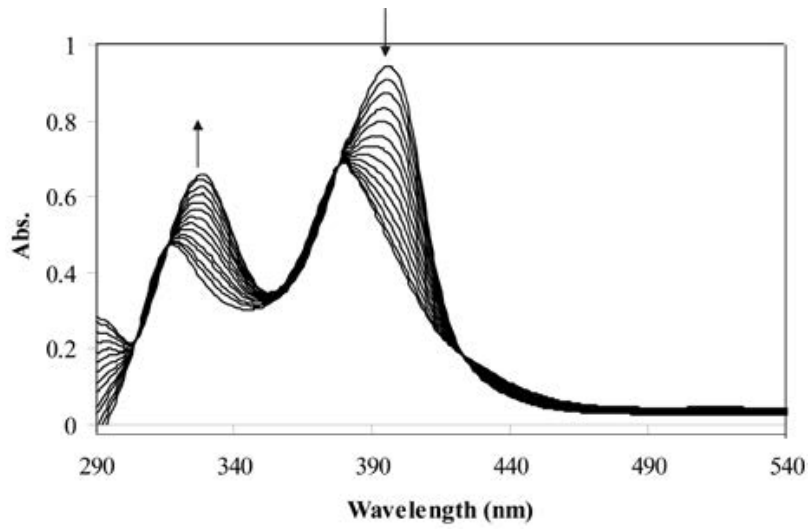

Figure 1. The variation of the electronic spectra of $\mathrm{H}_{2} \mathrm{~L}^{1}$ with $\mathrm{Cu}(\mathrm{II})$ acetate in DMF.

Table 4. The result of formation constants and the free energy values for the complexes

\begin{tabular}{|c|c|c|}
\hline Complexes & $\log K_{\mathrm{f}}$ & $\Delta G^{\circ}\left(\mathrm{kJ} \mathrm{mol}^{-1}\right)$ \\
\hline$\left[\mathrm{CuL}^{1}\right]$ & $5.88(0.10)^{\mathrm{a}}$ & $-33.55(0.24)$ \\
\hline$\left[\mathrm{CuL}^{2}\right]$ & $4.36(0.13)$ & $-24.86(0.32)$ \\
\hline
\end{tabular}

a The numbers in parentheses are the standard deviations.

\section{1. 4. Antibacterial Activity}

The results concerning in vitro antibacterial investigation of the Schiff base ligands and their copper(II) complexes (Table 5) show a remarkable inhibitor activity against pathogenic bacterial species of Gram positive and Gram negative bacteria. From comparison of observed data (Table 5), it is clear that the inhibition by the com- plexes is higher than that of corresponding ligands. This may be explained by the chelation theory. ${ }^{47,48}$ On one hand, chelation will reduced the polarity of the metal center because of overlap of the ligand orbital and partial sharing of positive charge of the metal atoms with donor atom present on the ligand. This fact leads to the increase in $\pi$-electron delocalization over the whole chelating ring. On the other hand, the chelation will enhanced the lipophilic character of the complexes. This, in turn, increase the diffusion of the complex through the lipid layer of the cell membranes and blocks the metal binding sites in the enzymes of bacteria. ${ }^{49,50}$

Inhibitory activity of the complexes is a follows $\left[\mathrm{CuL}^{2}\right]$ $>\left[\mathrm{CuL}^{1}\right]$. The activity depends on the properties of OMe group as electron releasing group and $\mathrm{NO}_{2}$ as electron withdrawing group on phenyl ring. This can be explained on basis of $\pi$-electron delocalization in chelating group as discussed above.

Table 5. Antibacterial screening results

\begin{tabular}{lcc}
\hline compounds & $\begin{array}{c}\text { E. coli } \\
\text { Diameter of }\end{array}$ & $\begin{array}{c}\text { S. aureus } \\
\text { Diabition zone }(\mathbf{m m})\end{array}$ \\
\hline $\mathrm{H}_{2} \mathrm{~L}^{1}$ & 20 & 21 \\
$\mathrm{H}_{2} \mathrm{~L}^{2}$ & 18 & 20 \\
{$\left[\mathrm{CuL}^{1}\right]$} & 29 & 26 \\
{$\left[\mathrm{CuL}^{2}\right]$} & 25 & 23 \\
tetracycline & 32 & 34 \\
\hline
\end{tabular}

\section{2. Computational Results}

\section{2. 1. Description of the Optimized Structures}

Molecular structure and atom notation of the compounds with selected bond distances and angles are shown in Figure 2 and Table 6. The Schiff base ligands are coordinated to the metal core through the amine nitrogen $(\mathrm{N} 1)$, azomethine nitrogen atom (N2), phenolic oxygen atom (O1) and thio sulfur atom (S2). The Cu1-N2, Cu1-N1, $\mathrm{Cu} 1-\mathrm{O} 1$ and $\mathrm{Cu} 1-\mathrm{S} 2$ bond distance in $\left[\mathrm{CuL}^{1}\right]$ and $\left[\mathrm{CuL}^{2}\right]$ are $1.966,1.960,1.908,2.346 \AA$ and $1.958,1.968,1.926$, $2.332 \AA$, respectively. All bond distances are in good agreement with those reported in other similar tetradentate Schiff base complexes. ${ }^{18,51}$ The calculated $\mathrm{C} 10-\mathrm{N} 1$ and $\mathrm{C} 3-\mathrm{N} 2$ bond length in the complexes are close to the value for a double bond, like in similar Schiff base complexes. ${ }^{16}$ Compared with the ligand, most of bonds show elongation upon complexation with the metal ion. C10-N1, C3-N2, C15-S2 and C6-O1 bond lengths become longer in both complexes in qualitative agreement with expectation. This finding is due to the formation of $\mathrm{Cu} 1-\mathrm{N} 1, \mathrm{Cu} 1-\mathrm{N} 2, \mathrm{Cu} 1-$ $\mathrm{O} 1$ and $\mathrm{Cu} 1-\mathrm{S} 2$ bonds which make the $\mathrm{C} 10-\mathrm{N} 1, \mathrm{C} 3-\mathrm{N} 2$, C6-O1 and C15-S2 bonds weaker. ${ }^{52}$ The high negative atom charge of imine nitrogen atoms $(\mathrm{N} 1, \mathrm{~N} 2)$, the phenolic oxygen atome $(\mathrm{O} 1)$ and thio sulfur (S2) is: -0.456 , 
$-0.441,-0.688,-0.179$ for $\mathrm{H}_{2} \mathrm{~L}^{1}$ and $-0.455,-0.436,-0.659$, -0.171 for $\mathrm{H}_{2} \mathrm{~L}^{2}$, respectively. These data suggest that the $\mathrm{O} 1$ atom donates more electron density to the copper ion leading to strong $\mathrm{Cu} 1-\mathrm{O} 1$ bonding. This idea corroborated by the short $\mathrm{Cu} 1-\mathrm{O} 1$ bond length in comparison to those of $\mathrm{Cu} 1-\mathrm{N} 1, \mathrm{Cu} 1-\mathrm{N} 2$ and $\mathrm{Cu} 1-\mathrm{S} 2 .{ }^{53}$

According to calculated results, the angles around the metal center for $\left[\mathrm{CuL}^{1}\right]$ and $\left[\mathrm{CuL}^{2}\right] \mathrm{N} 1-\mathrm{Cu} 1-\mathrm{O} 1\left(172.74^{\circ}\right.$, $\left.172.94^{\circ}\right), \quad \mathrm{N} 2-\mathrm{Cu} 1-\mathrm{S} 2\left(171.85^{\circ}, 171.68^{\circ}\right), \mathrm{N} 1-\mathrm{Cu} 1-\mathrm{S} 2$ $\left(90.78^{\circ}, 91.33^{\circ}\right)$ and $\mathrm{N} 2-\mathrm{Cu} 1-\mathrm{O} 1\left(90.71^{\circ}, 91.43^{\circ}\right)$ suggest distorted square planar geometry of the complexes. The dihedral angle between the phenyl and chelated ring is in the range $2.9-4.5^{\circ}$ (see Table 6) which indicates the resonance between phenyl groups with the $\pi$-electron system of the chelating ring.

There is a good agreement between the bond distance, bond angles and dihedral angles of the solid structure in similar compounds ${ }^{19,51}$ and gas phase calculated values. It a)

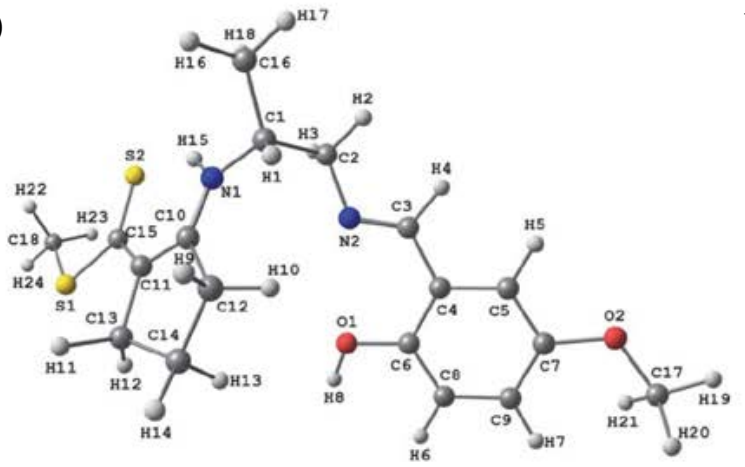

c)

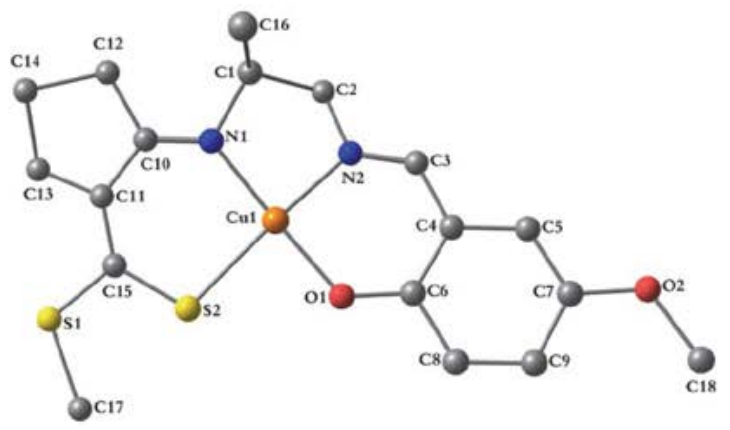

b)
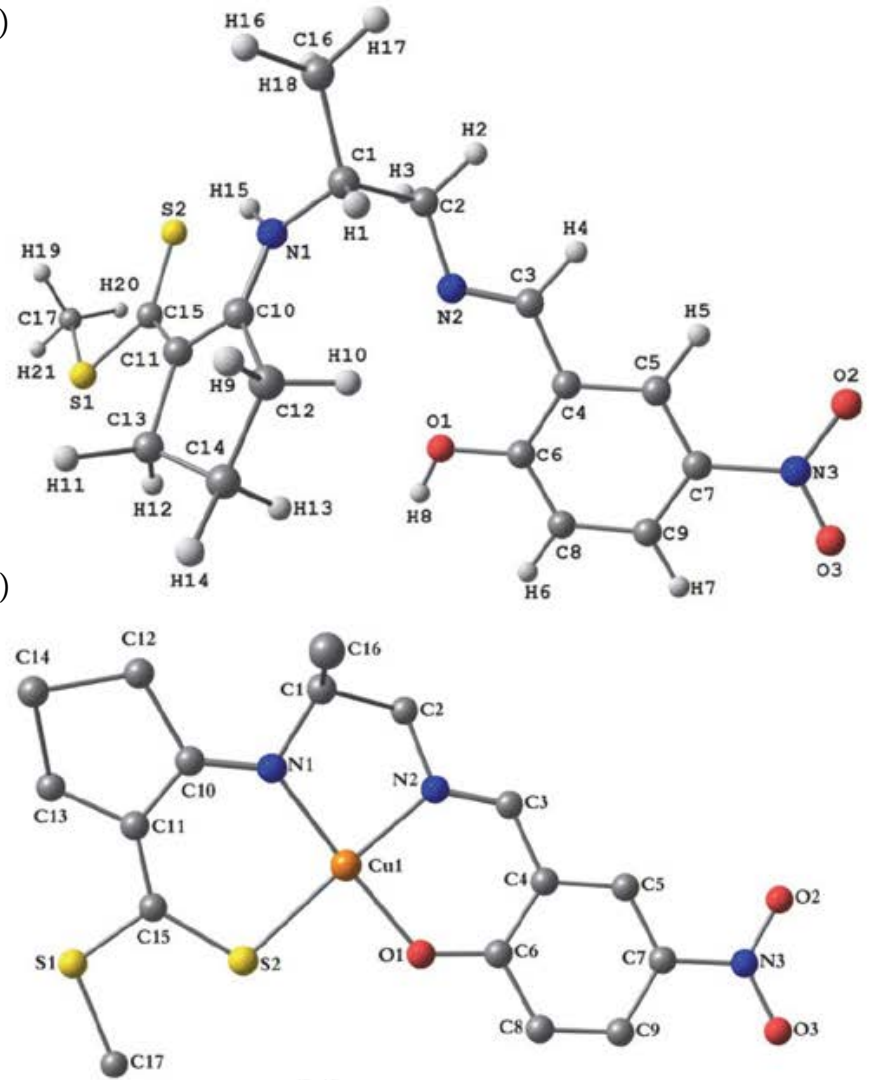

Figure 2. DFT optimized geometry of the (a) $\mathrm{H}_{2} \mathrm{~L}^{1},(\mathbf{b}) \mathrm{H}_{2} \mathrm{~L}^{2}$, (c) $\left[\mathrm{CuL}^{1}\right],(\mathbf{d})\left[\mathrm{CuL}^{2}\right]$ with labeling atoms (hydrogen atoms in both complexes have been omitted for clarity).

Table 6. Some selected optimized bond lengths and bond angles of the Schiff base ligands and its complexes

\begin{tabular}{|c|c|c|c|c|c|c|c|c|}
\hline \multicolumn{6}{|c|}{ Band length $(\AA)$} & \multicolumn{3}{|c|}{ Bond angle $\left(^{\circ}\right)$} \\
\hline & $\begin{array}{r}\text { Ligands } \\
\mathrm{H}_{2} \mathrm{~L}^{1}\end{array}$ & $\mathbf{H}_{2} \mathbf{L}^{2}$ & \multicolumn{3}{|c|}{ Complexes } & \multicolumn{2}{|c|}{$\begin{array}{r}\text { Complexes } \\
\text { CuL }^{1}\end{array}$} & $\mathrm{CuL}^{2}$ \\
\hline $\mathrm{N} 2-\mathrm{C} 3$ & 1.283 & 1.281 & $\mathrm{~N} 2-\mathrm{C} 3$ & 1.305 & 1.300 & $\mathrm{~N} 1-\mathrm{Cu}-\mathrm{N} 2$ & 86.508 & 86.587 \\
\hline $\mathrm{N} 1-\mathrm{C} 10$ & 1.325 & 1.326 & $\mathrm{~N} 1-\mathrm{C} 10$ & 1.339 & 1.340 & $\mathrm{~N} 1-\mathrm{Cu}-\mathrm{O} 1$ & 172.947 & 172.744 \\
\hline $\mathrm{C} 6-\mathrm{O} 1$ & 1.327 & 1.311 & $\mathrm{C} 6-\mathrm{O} 1$ & 1.392 & 1.376 & $\mathrm{~N} 1-\mathrm{Cu}-\mathrm{S} 2$ & 90.781 & 91.330 \\
\hline $\mathrm{C} 15-\mathrm{S} 2$ & 1.741 & 1.740 & C15-S2 & 1.762 & 1.764 & $\mathrm{~N} 2-\mathrm{Cu}-\mathrm{O} 1$ & 91.432 & 90.713 \\
\hline $\mathrm{C} 7-\mathrm{O} 2$ & 1.396 & - & $\mathrm{C} 7-\mathrm{O} 2$ & 1.404 & - & $\mathrm{N} 2-\mathrm{Cu}-\mathrm{S} 2$ & 171.692 & 171.851 \\
\hline $\mathrm{C} 7-\mathrm{N} 3$ & - & 1.457 & $\mathrm{C} 7-\mathrm{N} 3$ & - & 1.446 & $\mathrm{O} 1-\mathrm{Cu}-\mathrm{S} 2$ & 87.211 & 87.258 \\
\hline $\mathrm{O} 1-\mathrm{H} 8$ & 0.973 & 0.974 & $\mathrm{Cu} 1-\mathrm{N} 1$ & 1.966 & 1.968 & $\mathrm{O} 1-\mathrm{C} 6-\mathrm{C} 4-\mathrm{C} 3$ & 0.24046 & 0.36152 \\
\hline \multirow[t]{3}{*}{ N1-H15 } & 1.024 & 1.024 & $\mathrm{Cu} 1-\mathrm{N} 2$ & 1.960 & 1.958 & $\mathrm{~N} 2-\mathrm{C} 3-\mathrm{C} 4-\mathrm{C} 6$ & 1.18439 & 1.25585 \\
\hline & & & $\mathrm{Cu} 1-\mathrm{O} 1$ & 1.908 & 1.916 & N1-C10-C11-C15 & 4.27604 & 4.35552 \\
\hline & & & $\mathrm{Cu} 1-\mathrm{S} 2$ & 2.346 & 2.332 & $\mathrm{~S} 2-\mathrm{C} 15-\mathrm{C} 11-\mathrm{C} 10$ & 3.04373 & 2.91583 \\
\hline
\end{tabular}


should be noted that some differences are due to the X-ray crystal diffraction being applied in the solid phase, while theoretical calculations were carried out in the gas phase. ${ }^{10,54}$

Careful analysis of the bond lengths and bond angles data leads to the conclusion that $\mathrm{Cu}$ complex has a distorted square planar coordination around the $\mathrm{Cu}^{\mathrm{II}}$ center.

\section{2. 2. Details of Frontier Molecular Orbital Analysis}

The HOMO and LUMO molecular orbitals which are called the frontier orbitals and energy level of all mentioned compounds in this study was done using B3LYP/ (LANL2DZ/6-311G**) methods. 3D plots of the frontier orbital shapes and their corresponding energy levels are depicted in Figure 3 and Table 7 . The $E_{\mathrm{HOMO}}$ and $E_{\mathrm{LUMO}}$ for all compounds are negative indicating molecules are stable. The plots of HOMO and LUMO orbitals of the ligands show the HOMO surface is mainly located on the cyclo- pentene ring whereas the LUMO surface is mostly composed on the phenolic aromatic ring. ${ }^{55}$ This LUMO surface is overlapped with C15-S2 and C3-N2 group.

The computed frontier gap $\left(E_{\mathrm{HOMO}}-E_{\mathrm{LUMO}}\right)$ is very useful indicator in presenting the factors influencing the stability of these compounds. Taking this fact into the consideration, the energy gap levels for the compounds were computed (Table 7). The calculated $E_{\mathrm{g}}$ for the ligands is smaller than their complexes, indicating that the ligands are reactive and kinetically unstable. Since the ligand is more polarized the amount of electron charge transfer from the ligands to the metal increase, i.e. the ligand is soft molecule and easily offer electrons to an acceptor metal centers. ${ }^{53,56}$ For $\left[\mathrm{CuL}^{2}\right]$ complex, the HOMO orbital includes $\pi(\mathrm{L})(87 \%)$ character from ligand heteroatom along with minor contribution of $d \pi(\mathrm{Cu})$ orbital $(13 \%)$. This orbital has $\pi$-bonding nature which is concentrated on the chelated ligand. The LUMO orbital has $68 \% \pi^{\star}(\mathrm{L})$ character and significant contribution $(32 \%)$ of $\mathrm{d} \pi(\mathrm{Cu})$ orbital. The analysis of molecular orbitals for $\left[\mathrm{CuL}^{2}\right]$ complex is

a)
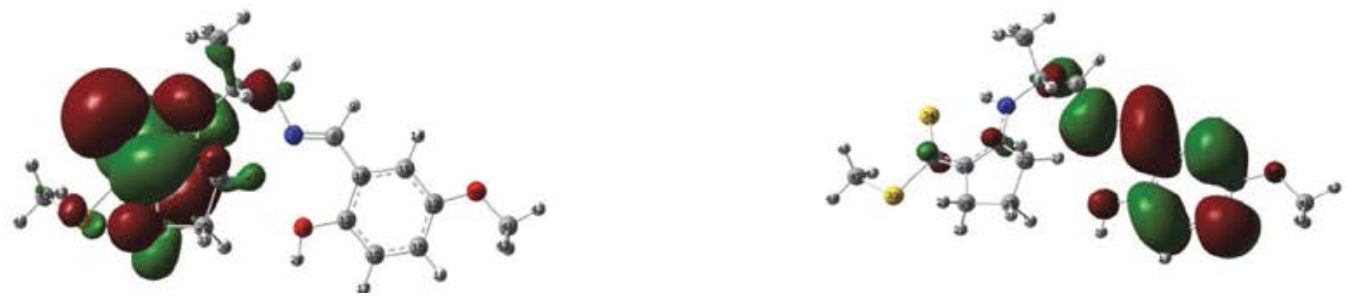

b)
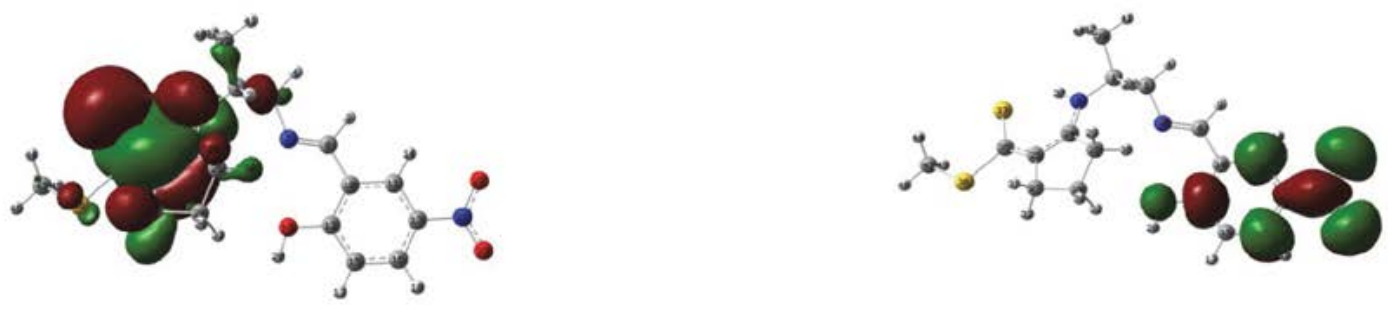

c)
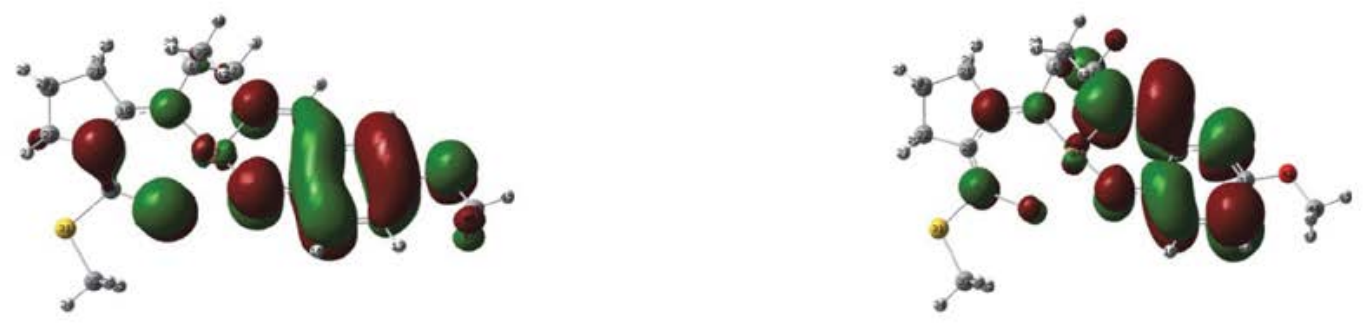

d)
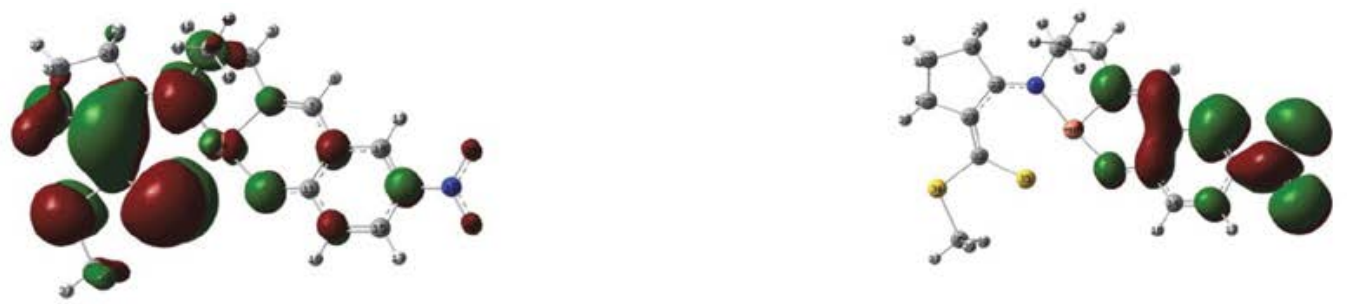

Figure 3. The HOMO (left) and LUMO (right) frontier orbitals views of (a) $\mathrm{H}_{2} \mathrm{~L}^{1}$, (b) $\mathrm{H}_{2} \mathrm{~L}^{2}$, (c) $\left[\mathrm{CuL}^{1}\right]$, (d) $\left[\mathrm{CuL}^{2}\right]$ 
more or less the same as for $\left[\mathrm{CuL}^{1}\right]$ complex. The calculated $E_{\mathrm{g}}$ level for the complexe show the $E_{\mathrm{g}}\left[\mathrm{CuL}^{1}\right]$ complex is larger than that $\left[\mathrm{CuL}^{2}\right]$ complex indicating the chemical reactivity of the $\left[\mathrm{CuL}^{1}\right]$ decrease and the complex is more stable. This results support the experimental formation constant.

\section{2. 4. Theoretical Study of Hardness, Mulliken Charges and Dipole Moment}

To rationalize the relative stability and reactivity of chemical compounds the chemical hardness is useful parameter. The hardness $\eta$ was calculated from $1 / 2(\mathrm{IE}-\mathrm{EA})$ equation, where IE and EA are the ionization energy and

Table 7. Some of calculated structural parameters for the Schiff base ligand and their Cu(II) complexes

\begin{tabular}{lcccccc}
\hline Complexes & HOMO/eV & LUMO/eV & gap/eV & Hardness $(\boldsymbol{\eta})$ & Dipole/Debye & HF energy (a.u.) \\
\hline $\mathrm{H}_{2} \mathrm{~L}^{1}$ & -5.417 & -3.298 & 2.119 & 1.059 & 3.169 & -1756.632 \\
$\mathrm{H}_{2} \mathrm{~L}^{2}$ & -5.526 & -3.264 & 2.262 & 1.131 & 3.182 & -1846.602 \\
{$\left[\mathrm{CuL}^{1}\right]$} & -5.281 & -1.633 & 3.648 & 1.824 & 5.865 & -3395.988 \\
{$\left[\mathrm{CuL}^{2}\right]$} & -5.852 & -2.613 & 3.239 & 1.615 & 5.860 & -3485.966 \\
\hline
\end{tabular}

\section{2. 3. Theoretical Study of Vibration Mode}

Vibrational frequency calculations were performed on the optimized structures of the complexes to search for the imaginary frequency and obtain the vibrational frequencies of compounds in gas phase. Table 1 shows selected experimental and calculated IR band assignments of studied Schiff base ligands and their $\mathrm{Cu}(\mathrm{II})$ complexes. The broad band related to $\mathrm{O}-\mathrm{H}$ stretching vibration of the phenolic group appears at 3410 and $3455 \mathrm{~cm}^{-1}$ in the free ligands spectrum. In the complexes, the $\mathrm{O}-\mathrm{H}$ peak disappear which indicates coordination of phenolic oxygen atom to central atom.

The multiple bands at around $3000 \mathrm{~cm}^{-1}$ in the ligands and their complexes are assigned to $\mathrm{C}-\mathrm{H}$ stretching vibration.

The strong bands at 1653 and $1668 \mathrm{~cm}^{-1}$ in the IR spectra of the Schiff base ligands assigned to the $v(\mathrm{C}=\mathrm{N})$ are changed by $17-22 \mathrm{~cm}^{-1}$ in the spectra of the complexes, indicating coordination of Schiff base through azomethine nitrogen atom.

The intense band in the $1400 \mathrm{~cm}^{-1}$ region is due to the skeleton vibration mode of $\mathrm{C}=\mathrm{C}$ in the free ligands and their copper(II) complexes.

The $v(\mathrm{C}-\mathrm{O})$ vibrations were found at $1260 \mathrm{~cm}^{-1}$ and $1283 \mathrm{~cm}^{-1}$ in the spectrum of the free ligands. These bands are shifted to lower or higher frequencies after complexation suggesting that this group takes part in coordination. The Schiff base ligand coordination to the copper ion is substantiated by two medium intensity bands at 470 and $472 \mathrm{~cm}^{-1}$ for $\left[\mathrm{CuL}^{1}\right]$ and $\left[\mathrm{CuL}^{2}\right]$, respectively, attributed to $v(\mathrm{M}-\mathrm{N})$ and also at 555 and $581 \mathrm{~cm}^{-1}$ for $\left[\mathrm{CuL}^{1}\right]$ and $\left[\mathrm{CuL}^{2}\right]$, respectively, for $v(\mathrm{M}-\mathrm{O})$ stretching frequencies. ${ }^{41,57}$

Ssmall differences between the theoretical and experimental vibrational frequencies can be related to (i) the environmental condition (gas phase and solid state) and (ii) from the fact that the experimental values are anharmonic frequencies while the calculated values are harmonic. ${ }^{58}$ electron affinity, respectively. The ionization energy and the electron affinity can be equalized through frontier orbital energies $\left(\mathrm{EA}=-\mathrm{E}_{\mathrm{HOMO}}\right.$ and $\left.\mathrm{IE}=-\mathrm{E}_{\mathrm{LUMO}}\right)$ according to the Koopman theorem. ${ }^{59}$ Therefore, for the calculation of hardness the following equation $\eta=1 / 2\left(\mathrm{E}_{\mathrm{HOMO}}-\mathrm{E}_{\mathrm{LUMO}}\right)$ was used for all titled compounds. ${ }^{60}$ As can be seen in Table 7 , the $\mathrm{H}_{2} \mathrm{~L}^{2}$ ligand and $\left[\mathrm{CuL}^{1}\right]$ complex have a higher hardness and lower chemical reactivity and higher stability than the other compounds.

Dipole moment is fundamental characteristics to explain the polarization of compounds. The experimental measurements of dipole moment are not always feasible, so we were using the density functional theory to calculate this parameter. On the basis of magnitude of dipole moments (Table 7) all studied compounds are polar. The $\left[\mathrm{CuL}^{2}\right]$ complex has the smallest dipole moment; that in part explains the instability of the $\left[\mathrm{CuL}^{2}\right]$ and the decrease the formation constant.

The values of the computed Mulliken net charge on non-hydrogen atoms (active centers) were investigated. Electronegativity plays important role on atomic charge distributions of the non-hydrogen atom. When two atoms are connected together, the atom having higher electronegativity will carry negative charges, while the atom having smaller electronegativity will carry positive charges. As summarized in Table 8, when the carbon is bonded to N1, $\mathrm{N} 2, \mathrm{O} 1$ and S2 atoms, the carbon atomic charges are positive and the most negative atomic charges are attributed to $\mathrm{N} 1, \mathrm{~N} 2, \mathrm{O} 1$ and S2 which have higher electronegativity than the carbon. On the other hand, the results show that the most negative centers in the ligand are bonded to metal ions which carry the positive charge value (Table 8). After complexation, the charge density decrease on the donating atom indicating that the metal ions received the electron density from their surrounding donating sites with high negative charge centers of the ligand. The calculated net charge of the complexes were compared with that free Schiff base ligand in order to show the donating sites in the ligand involved in the chelation and support one of our original ideas of the synthesis. 
Table 8. Selected values for the Mulliken charge distributions for non-hydrogen atoms

\begin{tabular}{lcccc}
\hline $\begin{array}{c}\text { Compounds } \\
\text { Charge }\end{array}$ & $\mathbf{H}_{\mathbf{2}} \mathbf{L}^{\mathbf{1}}$ & $\mathbf{H}_{\mathbf{2}} \mathbf{L}^{\mathbf{2}}$ & {$\left[\mathrm{CuL}^{\mathbf{1}}\right]$} & {$\left[\mathrm{CuL}^{\mathbf{2}}\right]$} \\
\hline Cu1 & - & - & 1.15996 & 1.15719 \\
N1 & -0.45654 & -0.45576 & -0.39787 & -0.30551 \\
N2 & -0.44166 & -0.43669 & -0.43459 & -0.42802 \\
S2 & -0.17963 & -0.17113 & -0.14996 & -0.13995 \\
O1 & -0.68843 & -0.65924 & -0.37940 & -0.36719 \\
C1 & 0.19197 & 0.08296 & 0.12969 & 0.13045 \\
C2 & 0.14316 & 0.19723 & 0.17083 & 0.17661 \\
C3 & 0.20375 & 0.03683 & 0.17469 & 0.18212 \\
C6 & 0.27879 & 0.29780 & 0.38667 & 0.41059 \\
C7 & 0.24649 & 0.26943 & 0.21392 & 0.23924 \\
C10 & 0.45997 & 0.46642 & 0.37940 & 0.38437 \\
C11 & 0.22702 & 0.22699 & 0.24055 & 0.24050 \\
C15 & 0.48696 & 0.61489 & 0.49136 & 0.49244 \\
\hline
\end{tabular}

\section{Conclusion}

The present study describes the synthesis and characterization of some Schiff base ligands and their $\mathrm{Cu}^{\mathrm{II}}$ complexes. From the IR and UV-Vis spectra it may be concluded the Schiff base ligand acts as a chelating to the metal ion and bind through nitrogen atoms of the azomethine and amine groups, phenolic oxygen atom and sulfur atom of the $\mathrm{C}=\mathrm{S}$ group. The stability constant and Gibbs free energy calculations show that the $\left[\mathrm{CuL}^{1}\right]$ complex is more stable than $\left[\mathrm{CuL}^{2}\right]$ complex. The present computational study allows us to obtain optimized structure, molecular parameters, highest occupied molecular orbital energy, lowest unoccupied molecular orbital energy, HOMO-LUMO band gap, IR vibrational frequencies, characteristics of all synthesized compounds. In general a good agreement was found between the theoretical and experimental data. The titled compounds in this study were tasted against two pathogenic bacteria in order to assess their antibacterial properties. The results revealed that the complexes possess higher antibacterial activity as free Schiff base ligands. Both complexes are effective catalysts for the cyclization reactions. The percentage product of reactions show $\left[\mathrm{CuL}^{2}\right]$ complex being more active then $\left[\mathrm{CuL}^{1}\right]$ complex.

\section{Acknowledgements}

We are grateful to Islamic Azad University, Darab branch Council for their financial support.

\section{References}

1. Y. W. Dong, R. Q. Fan, W. Chen, H. J. Zhang, Y. Song, X. Du, P. Wang, L. G. Wei, Y. L. Yong. Dalton Trans. 2017, 46, 1266-
1276. DOI:10.1039/C6DT04159K

2. J. Kumar, A. Rai, V. Raj, Org. Med. Chem. Int. J. 2017, 1, 1-15. 3. M. L. Low, L. Maigre, M. I. M. Tahir, E. R. T. Tiekink, P. Dorlet, R. Guillot, T. B. Ravoof, R. Rosli, J. M. Pages, C. Policar, N. Delsuc, K. A. Crouse, Eur. J. Med. Chem. 2016, 120, 1-12. DOI:10.1016/j.ejmech.2016.04.027

4. A. B. Gündüzalp, İ. Özsen, H. Alyar, S. Alyar, N. Özbek, J. Mol. Struct. 2016, 20, 259-266.

DOI:10.1016/j.molstruc.2016.05.002

5. H. G. Sogukömeroğullari, T. Taskin Tok, F. Yilmaz, L. Berber, M. Sonmez, Turk. J. Chem. 2015, 39, 497-509.

DOI:10.3906/kim-1412-81

6. Y. Mei Yu, K. Li, Y. Wang, Z. J. Yao, Polymers 2017, 9, 105-115. DOI:10.3390/polym9030105

7. A. Ourari, D. Aggoun, L. Ouahab, Inorg. Chem. Commun. 2013, 33, 118-124. DOI:10.1016/j.inoche.2013.04.002

8. A. Kareem, M. Arshad, Sh. A. A. Nami, N. Nishat, J. Photochem. Photobiol. Biol. 2016, 160, 163-171.

DOI:10.1016/j.jphotobiol.2016.03.030

9. I. R. Parrey, A. A. Hashmi, Canadian. Chem. Trans. 2015, 3, 65-71.

10. Z. Asgharpour, F. Farzaneh, A. Abbasi, M. Ghiasi, Polyhedron 2015, 101, 282-289. DOI:10.1016/j.poly.2015.09.030

11. K. H. Yang, Acta. Chim. Slov. 2014, 61, 629-639.

12. M. Mishra, K. Tiwari, P. Mourya, M. M. Singh. V. P. Singh, Polyhedron 2015, 89, 29-38. DOI:10.1016/j.poly.2015.01.003

13. P. Pattanayak, J. L. Pratihar, D. Patra, P. Brandão, V. Felix, Inorg. Chim. Acta 2014, 418, 171-179.

DOI:10.1016/j.ica.2014.04.021

14. P. Drabina, J. Svoboda, M. Sedlák, Molecules 2017, 22, 865883. DOI: $10.3390 /$ molecules 22060865

15. A. Bhattacharjee, Sh. Halder, K. Ghosh, C. Rizzoli, P. Roy, New. J. Chem. 2017, 41, 5696-5706.

DOI:10.1039/C7NJ00846E

16. S. Esmaielzadeh, L. Azimian, Kh. Shekoohi, H. Esfandiari, M. Asadi, Z. Zare, A. Rahmani nejad, K. Mohammadi, Inorg. Chim. Acta 2013, 405, 155-162.

DOI:10.1016/j.ica.2013.05.001

17. M. Asadi, K. Mohammadi, S. Esmaielzadeh, B. Etemadi, H. K. Fun, Polyhedron 2009, 28, 1409-1418.

DOI:10.1016/j.poly.2009.03.018

18. M. Asadi, K. Mohammadi, S. Esmaielzadeh, B. Etemadi, H. K. Fun, Inorg. Chim. Acta 2009, 362, 4913-4920.

DOI:10.1016/j.ica.2009.07.025

19. S. Esmaielzadeh, L. Azimian, K. Shekoohi, K. Mohammadi, Spectrochim. Acta Part A: Mol. Biomole. Spect. 2014, 133, 579-590. DOI:10.1016/j.saa.2014.05.095

20. S. Behrouz, M. N. Rad, S. Rostami, M. Behrouz, E. Zarehnezhad, A. Zarehnezhad, Mol. Divers. 2014, 18, 797-808. DOI:10.1007/s11030-014-9539-1

21. M. N. Rad, S. Behrouz, M. Behrouz, A. Sami, M. Mardkhoshnood, A. Zarenezhad, E. Zarenezhad, Mol. Divers. 2016, 20, 705-718. DOI:10.1007/s11030-016-9678-7

22. E. Zarenezhad, M. N. Rad, S. Behrouz, S. Esmaielzadeh, M. Farjam, J. Iran. Chem. Soc. 2017, 14, 509-519.

DOI:10.1007/s13738-016-0999-3 
23. S. G. Agalave, S. R. Maujan, V. S. Pore, Chem. Asian J. 2011, 6, 2696-2718. DOI:10.1002/asia.201100432

24. H. Sharghi, R. Khalifeh, M. M. Doroodmand, Adv. Synth. Catal. 2009, 351, 207-218. DOI:10.1002/adsc.200800612

25. E. Hashemi, Y. S. Beheshtiha, S. Ahmadi, M. M. Heravi, Trans. Met. Chem. 2014, 5, 593-601.

DOI:10.1007/s11243-014-9838-5

26. A. D. Becke, J. Chem. Phys. 1993, 98, 5648-5652. DOI:10.1063/1.464913

27. C. Lee, W. Yang, R. G. Parr, Phy. Rev. 1988, B 37, 785-789.

28. P. J. Hay, W. R. Wadt, J. Chem. Phys. 1985, 82, 270-283. DOI:10.1063/1.448799

29. M. J. Frisch, G. W. Trucks, H. B. Schlegel, G. E. Scuseria, M. A. Robb, J. R. Cheeseman, J. A. Montgomery, J. T. Vreven, K. N. Kudin, J. C. Burant, J. M. Millam, S. S. Iyengar, J. Tomasi, V. Barone, B. Mennucci, M. Cossi, G. Scalmani, N. Rega, G. A. Petersson, H. Nakatsuji, M. Hada, M. Ehara, K. Toyota, R. Fukuda, J. Hasegawa, M. Ishida, T. Nakajima, Y. Honda, O. Kitao, H. Nakai, M. Klene, X. Li, J. E. Knox, H. P. Hratchian, J. B. Cross, C. Adamo, J. Jaramillo, R. Gomperts, R. E. Stratmann, O. Yazyev, A. J. Austin, R. Cammi, C. Pomelli, J. W. Ochterski, P. Y. Ayala, K. Morokuma, G. A. Voth, P. Salvador, J. J. Dannenberg, V. G. Zakrzewski, S. Dapprich, A. D. Daniels, M. C. Strain, O. Farkas, D. K. Malick, A. D. Rabuck, K. Raghavachari, J. B. Foresman, J. V. Ortiz, Q. Cui, A. G. Baboul, S. Clifford, J. Cioslowski, B. B. Stefanov, G. Liu, A. Liashenko, P. Piskorz, I. Komaromi, R. L. Martin, D. J. Fox, T. Keith, M. A. Al-Laham, C.Y. Peng, A. Nanayakkara, M. Challacombe, P. M. W. Gill, B. Johnson, W. Chen, M. W. Wong, C. Gonzalez, J. A. Pople, Gaussian 03, Computer program for computational chemistry, Gaussian Inc., Pittsburgh PA, USA; 2004.

30. A. W. Bauer, W. M. Kirby, J. C. Sherris, M. Turck, Am. J. Clin. Pathol. 1966, 45, 493-496. DOI:10.1093/ajcp/45.4_ts.493

31. R. D. Walker, J. F. Prescott, J. D. Baggot. Antimicrobial susceptibility testing and interpretation of results, Iowa state university press, USA, 2000, pp. 12-26.

32. D. M. Abd El-Aziz, S. E. H. Etaiw, E. A. Ali, J. Mol. Struct. 2013, 1048, 487-499. DOI:10.1016/j.molstruc.2013.05.051

33. M. Slehi, F. Rahimifar, M. Kubicki, A. Asadi, Inorg. Chim. Acta 2016, 443, 28-35. DOI:10.1016/j.ica.2015.12.016

34. K. Ghosh, S. Roy, A. Ghosh, A. Banerjee, A. Bauzá, A. Frontera, S. Chattopadhyay, Polyhedron 2016, 112, 6-17. DOI:10.1016/j.poly.2016.02.035

35. X. M. Hu, L. W. Xue, G. Q. Zhao, W. C. Yang, Bull. Chem. Soc. Ethiop. 2015, 29, 407-413. DOI:10.4314/bcse.v29i3.8

36. A. Akbari, Z. Alinia, Turk. J. Chem. 2013, 37, 867-878. DOI:10.3906/kim-1207-74

37. D. Sakthilatha, R. Rajavel, J. Chem. Pharm. Res. 2013, 5, 5763.

38. A. Z. El-Sonbati, M. A. Diab, M. I. Abou-Dobara, H. A. Seyam, J. Mol. Liq. 2016, 218, 434-456.

DOI:10.1016/j.molliq.2016.02.072
39. S. Chandra, A. Rathi, J. Saudi, Chem. Soc. 2001, 5, 175-182.

40. R. B. Sumathi, M. B. Halli, Bioinorg. Chem. App. 2014, 2014, $1-11$.

41. M. Kudrat, E. Zahan, M. S. Islam, Russ. J. Gen. Chem. 2015, 85, 979-983. DOI:10.1134/S1070363215040350

42. Z. Asadi, M. Asadi, F. Dehghani Firuzabadi, R. Yousefi, M. Jamshidi, J. Iran. Chem. Soc. 2014, 11, 423-429.

DOI:10.1007/s13738-013-0314-5

43. D. F. Back, G. M. de Oliveira, L. A. Fontana, B. F. Romão, D. Roman, B. A. Iylesias, J. Mol. Struct. 2015, 1100, 264-271. DOI:10.1016/j.molstruc.2015.07.050

44. M. Asadi, Z. Asadi, N. Savaripoor, M. Dusek, V. Eigner, M. Ranjkesh, M. Sedaghat, Spectrochim. Acta Part A: Mol. Biomole. Spect. 2015, 136, 625-634.

DOI:10.1016/j.saa.2014.09.076

45. S. Basak, S. Sen, S. Mitra, C. Marschner, W. S. Sheldrick, Struct. Chem. 2008, 19, 115-121.

DOI:10.1007/s11224-007-9260-0

46. K. Singh, Y. Kumar, P. Puri, M. Kumar, C. Sharma, Eur. J. Med. Chem. 2012, 52,313-321. DOI:10.1016/j.ejmech.2012.02.053

47. D. L. Leggett. Computational Methods for the Determination of Formatioin Constant, Plenum Press, New York; 1985.

DOI:10.1007/978-1-4684-4934-1

48. L. Dawara, R. V. Singh, Appl. Organomet. Chem. 2011, 25, 643-652.

49. B. G. Tweedy, Phytopathology 1946, 55, 910-917.

50. N. Batra, N. Malhotra, S. Assija, J. Chem. Pharma. Res. 2014, 6, 194-200.

51. N. Kumar Chaudhary, P. Mishra, Am. J. Appl. Chem. 2014, 2, 19-26. DOI:10.11648/j.ajac.20140201.15

52. G. Grivani, S. Husseinzadeh Baghan, M. Vakili, A. Dehno Khalaji, V. Tahmasebi, V. Eigner, M. Dušek, J. Mol. Struct. 2015, 1082, 91-96. DOI:10.1016/j.molstruc.2014.10.058

53. O. A. El-Gammal, Spectrochim. Acta Part A: Mol. Biomole. Spect. 2010, 75, 533-542. DOI:10.1016/j.saa.2009.11.007

54. A. A. Khandar, C. Cardin, S. A. Hosseini-Yazdi, J. McGrady, M. Abedi, S. A. Zarei, Y. Gan, Inorg. Chim. Acta 2010, 363, 4080-4087. DOI:10.1016/j.ica.2010.08.019

55. Z. G. Niu, L. R. He, L. Li, W. F. Cheng, X. Y. Li, H. H. Chen, G. N. Li, Acta Chim. Slov. 2014, 61, 786-791.

56. O. A. El-Gammal, Inorg. Chim. Acta 2015, 435, 73-81. DOI:10.1016/j.ica.2015.06.009

57. A. Akbari, M. Jalili Rasti, Comput. Res. 2013, 1, 27-33.

58. M. Amirnasr, M. Bagheri, H. Farrokhpour, K. J. Schenk, K. Mereiter, P. C. Ford, Polyhedron 2014, 71, 1-7.

DOI:10.1016/j.poly.2013.12.040

59. T. Koopmans, Physica 1934, 1, 104-113. DOI:10.1016/S0031-8914(34)90011-2

60. S. Esmaielzadeh, L. Azimian, Z. Zare, Acta Chim. Slov. 2016, 63, 351-362. DOI:10.17344/acsi.2016.2335 


\section{Povzetek}

Sintetizirali smo dva nova bakrova(II) kompleksa s Schiffovimi bazami in ju okarakterizirali z različnimi fizikalno-kemijskimi in spektroskopskimi metodami, ki razkrivajo popačeno kvadratno planarno geometrijo okoli bakrovega atoma. Analizni podatki potrjujejo stehiometrijo kovina: ligand 1:1. S teorijo gostotnostnega funkcionala (DFT) na B3LYP/ (LANL2DZ/6-311G**) nivoju smo proučili strukturne in elektronske lastnosti pripravljenih spojin v vakuumu. Kvantno-mehanski rezultati potrjujejo zaključke dobljene na podlagi eksperimentalnih podatkov. Študij termodinamskih lastnosti tvorbe kompleksov smo izvedli spektrofotometrično pri $25^{\circ} \mathrm{C}$. Pri obeh spojinah smo testirali in vitro antibakterijsko aktivnost. Proučili smo tudi katalitične lastnosti na primeru klik reakcij. Sintetizirana bakrova kompleksa s Schiffovimi bazami katalizirata 1,3-dipolar Huisgenovo cikloadicijo različno funkcionaliziranih $\beta$-azido alkoholov in alkinov v prisotnosti askorbinske kisline v raztopini $\mathrm{THF} / \mathrm{H}_{2} \mathrm{O}(2: 1, \mathrm{~V} / \mathrm{V})$ pri sobni temperaturi. 